\title{
Correlation between fruit size and picking scar size in some organically grown highbush blueberries (Vaccinium corymbosum L.)
}

\author{
Hüseyin ÇELİK $(i)$, Seda ATEŞ $\left(D\right.$, Ali ÍSLAM ${ }^{(D 2}$ \\ ${ }^{1}$ Ondokuz Mayıs Üniversity, Agricultural Faculty, Horticultural Department, Samsun \\ ${ }^{2}$ Ordu Üniversity, Agricultural Faculty, Horticultural Department, Ordu
}

Alınış tarihi: 4 Aralık 2019, Kabul tarihi: 3 Ocak 2020

Sorumlu yazar: Hüseyin ÇELİK, e-posta: huscelik@omu.edu.tr

\begin{abstract}
This study was carried out to determine the correlation between fruit size and picking scar diameter of organically grown northern highbush blueberry cultivars. In the experiment, eight northern highbush blueberry cultivars (Toro, Brigitta, Darrow, Patriot, Bluecrop, Bluegold, Bluejay and Chandler) (Vaccinium corymbosum L.), have five years old plants and grows in Trabzon conditions, were used. The differences in the fruit size and the picking scar diameter among the cultivars, and the annual differences within each cultivar were studied. Berry width varied between $14.22-20.43 \mathrm{~mm}$ and fruit weight varied between $1.76-4.22 \mathrm{~g}$. While Chandler (2.86 - $3.14 \mathrm{~mm})$ had the biggest scar size, Patriot and Brigitta $(2.14-2.21 \mathrm{~mm})$ had the smallest scar size. Also, it was determined that picking scar size correlates with fruit width and weight for the harvest year. However, relationship between the fruit width and the scar size of eight cultivars is significantly positive.
\end{abstract}

Key words: Blueberry, berry, picking scar, relationship

Organik olarak yetiştirilen yüksek boylu maviyemişlerde meyve iriliği ile sap çukuru yara izi arasındaki ilişkiler

\section{Öz}

$\mathrm{Bu}$ çalışma organik olarak yetiştirilen kuzey orijinli yüksek boylu maviyemiş çeşitlerinde meyve büyüklüğü ile sap çukuru yara izi arasındaki ilişkileri ortaya koymak amacıyla yapılmıştır. Çalışmada
Trabzon ilinde organik olarak yetiștirilen ve beş yaşında bitkilere sahip olan sekiz adet kuzey orijinli yüksek boylu maviyemiş çeşidi (Toro, Brigitta, Darrow, Patriot, Bluecrop, Bluegold, Bluejay ve Chandler) (Vaccinium corymbosum L.) kullanılmıştır. Çeşitlerde hasatta ortaya çıkan sap çukuru yara izi ile meyve iriliği arasındaki ilişkiler ve farklılıklar incelenmiştir. Elde edilen sonuçlara göre maviyemiş çeşitlerinde meyve genişlikleri 14.22-20.43 mm, meyve ağırlıkları ise 1.76-4.22 g arasında değişmiştir. En iri meyvelere sahip olan Chandler çeşidindeki sap çukuru yara izi de yıllara göre 2.86$3.14 \mathrm{~mm}$ ile en yüksek değere ulaşmıştır. Patriot ve Brigitta çeşitlerinde ise sap çukuru yara izi 2.14-2.21 $\mathrm{mm}$ ile en düşük değeri vermiştir. Ayrıca, her iki hasat yılında da maviyemişlerde sap çukuru yara izi çapı ile meyve iriliği arasında pozitif ilişki olduğu saptanmıștır. Bununla birlikte maviyemiş çesitlerinin tamamında meyve genişliği ile sap çukuru yara izi arasında da pozitif ilişki olduğu da ortaya konulmuştur.

Anahtar kelimeler: Maviyemiş, meyve büyüklüğü, sap çukuru yara izi, interaksiyon

\section{Introduction}

Blueberry breeders search for cultivars whose fruits are mainly characterized by high firmness, a large size and a small scar where the pedicel detaches (picking scar) (Konarska, 2015). Picking scar size is the main character that might influence blueberry commercialization (Ballington et al., 1986; Galletta and Ballington, 1996). Large berries prefer by customers on fresh blueberry market, while small 
berries are appropriate for pancake or jelly-making. In both cases, berries with small scar are preferable, as the picking scar favors pathogen penetration (Ballington et al., 1984; Galletta and Ballington, 1996). Thus, it is advantageous to select plants which produce large fruits with small picking scar. Ballington et al. (1984) reported that the picking scar size and berry weight increase with ploidy level and the picking scar will be larger when the fruits are big. This trend was also discussed by Ballington et al. (1984) for several wild Vaccinium species and four highbush and rabbiteye blueberry cultivars, grown in America. Several species of Vaccinium are important for commercial production. The most common blueberry cultivars belong to highbush and rabbiteye blueberries grown worldwide (Strik and Finn, 2008). Highbush blueberries also separated into northern and southern types depending on their chilling requirements and winter hardiness (Hancock et al. 2008). In Turkey, the northern highbush blueberry cultivars like Bluecrop, Brigitta and Patriot were grown extensively. Blueberries have very specific soil requirements. Plants grow best in well-drained, light, sandy loam soils that are high in organic matter and have a pH between 4.5 and 5.5 (Strik, 2008). In the Black Sea Region of Turkey, many locations have natural and optimum acidic $(\mathrm{pH}=4.6-5.5)$ soils. Owing to the sloping topography of this region, many blueberry orchards established in terraces for technical and cultural practices to harvest can perform easily (Ateş and Çelik, 2013). Berry set vary according to the species and varieties and berry set ratio of northern highbush blueberry is between $55-100 \%$. Blueberry fruit is actual berry and desirable fruit characteristics are large size, light blue color, firm fruit, resistance to cracking, good keeping quality and good aroma and flavor. In addition, the tendency for fruit to remain on the plant rather than drop when ripe and a small dry fruit scar that reduces decay after harvest are desirable (Çelik, 2012; Strang et al., 1989). There is not much study on the relationship between picking scar and fruit weight for blueberries. Konarska (2015) conclude that a smaller picking scar result good firmness and scar size varies depending on the cultivar. It was found in the study that the diameter of picking scar in the Patriot fruits was substantially smaller. Similar results were obtained by Ballington et al. (1984) and Perkins-Veazie et al. (1994) who indicated little or no relationship between the scar diameter and fruit size amongst various cultivars and Vaccinium species. In turn, Parra et al. (2007) show that the size of the picking scar, which is larger in bigger and heavier fruits, is an important quality trait of blueberry cultivar. Many authors also stated that picking scar has a genetic background and the large diameter of the picking scar can promote rapid water loss and facilitate by fungal and bacterial pathogens causing fruit decay (Konarska, 2015). Moggia et al. (2017) found that fruit with large scar were larger (greater in weight, length and diameter) than those with a medium or small scar for two of the family studies.

In this study we aimed to determine the fruit width and diameter, picking scar diameter and fruit weight of organically grown northern highbush blueberries and correlate fruit diameter and weight to picking scar.

\section{Materials and Methods}

The experiment was set in two years in Hayrat district of Trabzon. Five-year-old northern highbush blueberry plants of Toro, Brigitta, Darrow, Patriot, Bluecrop, Bluegold, Bluejay and Chandler were planted at $1.5 \times 2 \mathrm{~m}$ in and between row spaces. The raised beds with cattle stable manure were mulched with aged tea waste laid for a $60 \mathrm{~cm}$ wide and $5 \mathrm{~cm}$ thick. Two-line drip irrigation was used. Each plot consisted of 15 plants and the experiment had three replicates in a completely randomized block design. Fifty ripe fruits were gathered randomly from several branches of one plant of each commercial cultivar in the study. Samples were collected for 2 years during the first, second and third harvest when the fruits of each plant or cultivar were ripe. Five morphometric variables were considered: Fruit length and width, picking scar size, fruit width, and weight. The scar size was measured by a digimatic caliper with a measurement amplitude of 0-150 mm, and an error of $0.01 \mathrm{~mm}$ (Mitutoyo Ltd., UK). Individual fruits were weighed by an electronic balance A\&D (Engineering Inc., Milpitas, CA, USA, FY200). Berries were picked by hand. Samples taken from each harvest during June and July. Berry width, picking scar and fruit weight were measured in the laboratory. The three morphometric variables were checked for normality and homoscedasticity. Results were subjected by the analyses of variance (ANOVA). Duncan's multiple range test was used for mean separation $(\mathrm{P}<0.05)$. For cultivars, a Pearson correlation analysis was applied to the data to determine the relationship between the fruit size (width and weight) and the picking scar diameter. 


\section{Results and Discussion}

The mean fruit width varied from 14.22 (Bluejay) to $20.43 \mathrm{~mm}$ (Chandler) in the first year (Table 1, Fig. 1). The lowest picking scar size was recorded in Patriot $(2.14 \mathrm{~mm})$ and the highest in Chandler (2.86 $\mathrm{mm}$ ) while the lowest fruit weight retained in Bluejay (1.81 g) with Bluegold (1.81 g) and the highest in Chandler (4.22 g) (Table 1, Fig. 1). According to the early studies, Eccher et al. (2006) and Starast et al. (2009) indicated that Toro had the $1.55 \mathrm{~g}$ berry weight and $14.9 \mathrm{~mm}$ width while Patriot (2.12 $\mathrm{g}$ and $16.27 \mathrm{~mm}$ ), Bluegold (1.59 $\mathrm{g}$ and 14.45 $\mathrm{mm}$ ), Bluecrop (0.6 g and $18 \mathrm{~mm}$ ), Bluejay ( $0.7 \mathrm{~g}$ and $16 \mathrm{~mm})$ and Chandler $(0.7 \mathrm{~g}$ and $20 \mathrm{~mm})$ grown in different country. This proved that berry weight and width depends on cultivar, growing area as well as technical and cultural practices (Retamales and Hancock, 2018). Smolarz (2006) and Paprstein et al. (2009) also observed that the weight of 100 fruits of Bluecrop, Bluegold and Toro is $164 \mathrm{~g}, 157 \mathrm{~g}$, and 152 g, respectively. Scalzo et al. (2009a) observed that the picking scar size varies between 1.8 and $3 \mathrm{~mm}$ for Bluecrop and Duke.

In the present study, the mean fruit width varied from 14.24 (Toro) to $20.41 \mathrm{~mm}$ (Chandler) in the second year. The lowest picking scar size was recorded in Brigitta $(2.21 \mathrm{~mm})$, the highest in Chandler $(3.14 \mathrm{~mm})$ while the lowest fruit weight retained in Bluejay (1.76 g) and the highest in Chandler (3.99 g) (Table 1). In both harvest year, several cultivars have the highest picking scar show the highest berry weight like Chandler, Darrow and Bluecrop. According to Çelik (2012), Chandler and Darrow have big berry and they are good for fresh consumption. The results of studies on some highbush blueberry cultivars in the world were indicated that the mean fruit weight varies between 0.6- $2.8 \mathrm{~g}$ while weight of 100 fruits varies from 48 to $197 \mathrm{~g}$. The mean fruit width varies from 13.44 to 20 mm (Eccher et al., 2006; Bal et al., 2006; Dale and Hancock, 2005; Smolarz, 2006; Paprstein et al., 2009; Starast et al., 2009; Siefker and Hancock, 1986). The mean fruit weight of Bluecrop (2.4 g), Toro (2.1 g), Bluegold (1.6 g), Brigitta Blue (1.7 g), Bluegold (1.4 g) and Bluejay (1.26 g) varieties were retained in Netherlands, Canada and America (Bal et al., 2006; Dale and Hancock, 2005; Siefker and Hancock, 1986). The mean fruit weight (1-4 g), width (11-21 mm) and picking scar size $(1.5-3 \mathrm{~mm})$ were examined of
'Hortblue Poppins', Reka, Nui, Duke and Bluecrop highbush blueberry varieties (Scalzo et al., 2009b).

The correlations between fruit width, weight and picking scar size in highbush blueberries in the first and second years show that the picking scar size correlates with all of variables (Table 2). It was proved that picking scar size correlates with fruit width and fruit weight both years. Five rabbiteye and nine southern highbush commercial cultivars with 38 hybrid plants used within a blueberry research program in Spain. This research determined that the picking scar size correlates with fruit width and weight (Parra et al., 2007). This study encouraged to our research results.

In the first year, the mean summer temperature value of Turkey was higher than second year. Also it was retained that rainfall of Hayrat-Trabzon province in the first year (not shown here) was much lower than the second year. Therefore, berries puckered and berry width, weight and picking scar diameter reduced generally in the first year when compared to second year.

The scatter diagrams of Figure 2 show relationship between the fruit width and the scar size in three replicates of eight commercial cultivars in the first year. There is significant and positive relationship between fruit width and scar size $(R=0.619$; $\mathrm{p}=0.001)$.
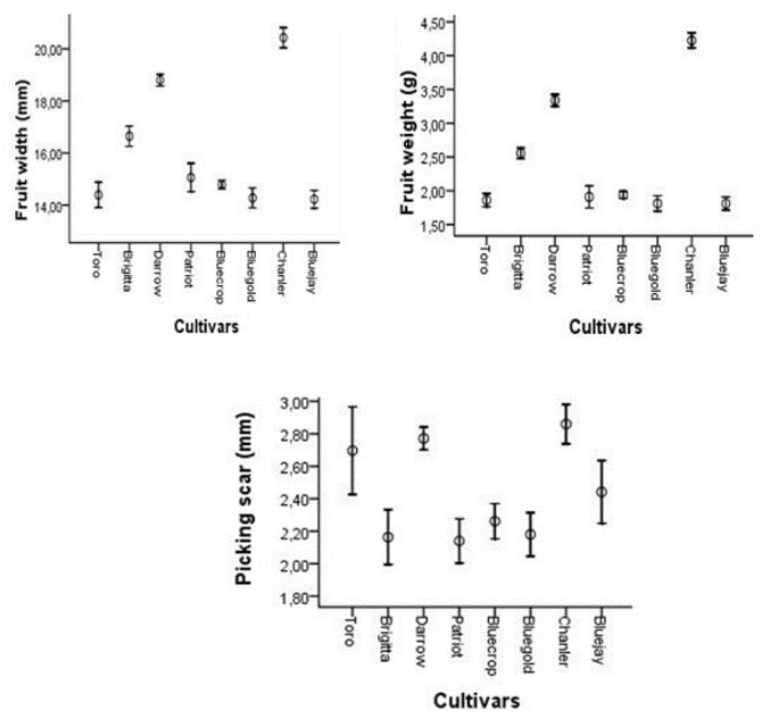

Figure 1. Error diagrams of eight northern highbush blueberry cultivars for fruit width, picking scar size and fruit weight characters 
Table 1. Means for fruit width, picking scar diameter and fruit weight for highbush blueberry cultivars in the first harvest year

\begin{tabular}{|c|c|c|c|c|c|c|}
\hline Cultivars & $\mathrm{FW}^{*}(\mathrm{~mm})$ & $\mathrm{PSD}^{*}(\mathrm{~mm})$ & FWT* $^{*}(\mathrm{~g})$ & $\mathrm{FW}^{*}(\mathrm{~mm})$ & $\mathrm{PSD}^{*}(\mathrm{~mm})$ & $\mathrm{FWT}^{*}(\mathrm{~g})$ \\
\hline \multicolumn{4}{|c|}{ First harvest year } & \multicolumn{3}{|c|}{ Second harvest year } \\
\hline Toro & $14.39 \mathrm{de}^{* *}$ & $2.70 \mathrm{ab}$ & $1.86 \mathrm{~d}$ & $14.24 \mathrm{e}^{*}$ & $2.47 \mathrm{~b}$ & $1.77 \mathrm{e}$ \\
\hline Brigitta & $16.65 \mathrm{c}$ & $2.16 \mathrm{c}$ & $2.56 \mathrm{c}$ & $16.87 \mathrm{c}$ & $2.21 \mathrm{c}$ & $2.49 \mathrm{c}$ \\
\hline Darrow & $18.80 \mathrm{~b}$ & $2.77 \mathrm{a}$ & $3.34 \mathrm{~b}$ & $17.56 \mathrm{~b}$ & $2.97 \mathrm{a}$ & $2.75 \mathrm{~b}$ \\
\hline Patriot & $15.06 \mathrm{~d}$ & $2.14 \mathrm{c}$ & $1.91 \mathrm{~d}$ & $16.40 \mathrm{c}$ & $2.49 \mathrm{~b}$ & $2.47 \mathrm{c}$ \\
\hline Bluecrop & $14.79 \mathrm{de}$ & $2.26 \mathrm{c}$ & $1.94 \mathrm{~d}$ & $16.61 \mathrm{c}$ & $3.11 \mathrm{a}$ & $2.42 \mathrm{c}$ \\
\hline Bluegold & $14.28 \mathrm{e}$ & $2.18 \mathrm{c}$ & $1.81 \mathrm{~d}$ & $15.25 \mathrm{~d}$ & $2.54 \mathrm{~b}$ & $2.00 \mathrm{~d}$ \\
\hline Chandler & $20.43 \mathrm{a}$ & $2.86 \mathrm{a}$ & $4.22 \mathrm{a}$ & $20.41 \mathrm{a}$ & $3.14 \mathrm{a}$ & $3.99 \mathrm{a}$ \\
\hline Bluejay & $14.22 \mathrm{e}$ & $2.44 \mathrm{bc}$ & $1.81 \mathrm{~d}$ & $14.47 \mathrm{e}$ & $2.61 \mathrm{~b}$ & $1.76 \mathrm{e}$ \\
\hline
\end{tabular}

*FW: Fruit width, PSD: Picking scar diameter, FWT: Fruit weight

** The differences between the means indicated by different letters in the same column $(\mathrm{p}<0.05)$ is significant.

Table 2. Pearson's bilateral correlation coefficients (R) between the three variables analyzed in highbush blueberries in the first harvest year

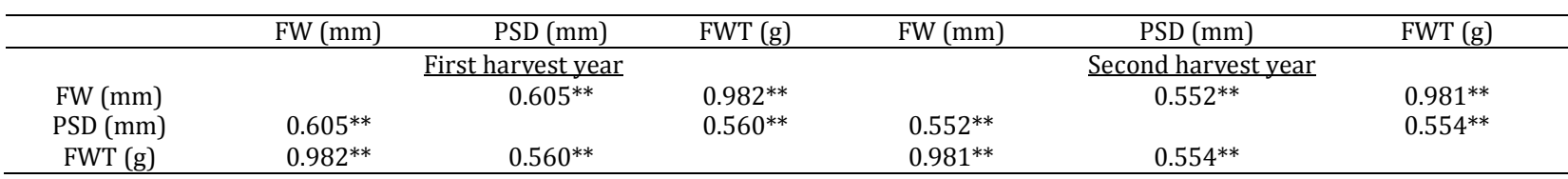

*FW: Fruit width, PSD: Picking scar diameter, FWT: Fruit weight

** Correlation is significant at the 0.01 level.

The scatter diagrams of Figure 3 show relationship between the fruit width and the scar size in three replicates of eight commercial cultivars in the second year. There is significant and positive relationship between fruit width and scar size, too $(\mathrm{R}=0.586$; $\mathrm{p}=0.003$ ).

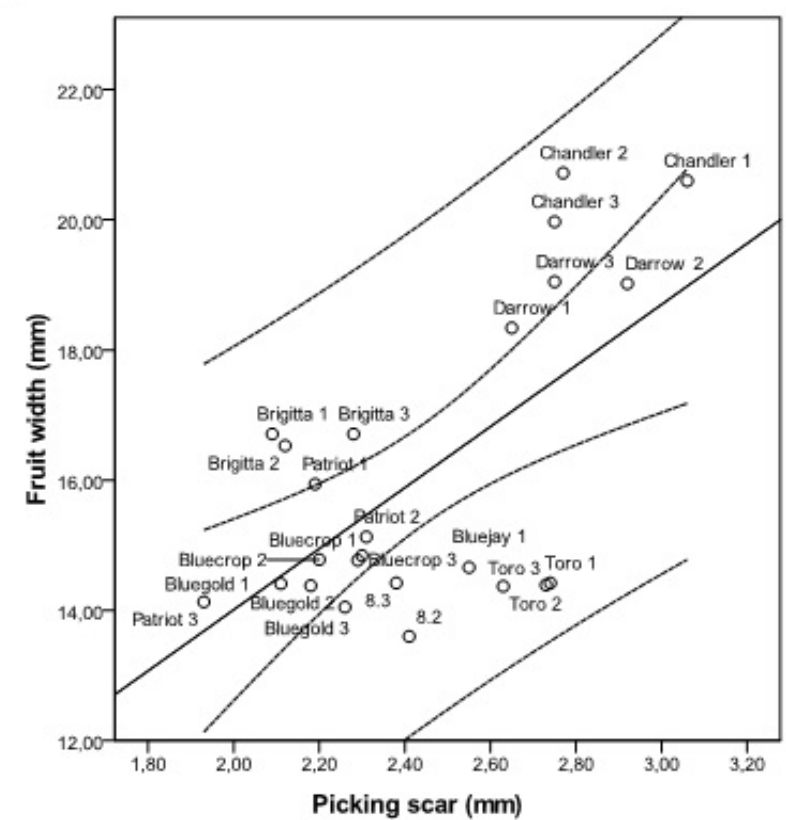

Figure 2. Correlation between fruit width and picking scar size from three replicates for eight commercial cultivars in the first harvest year.

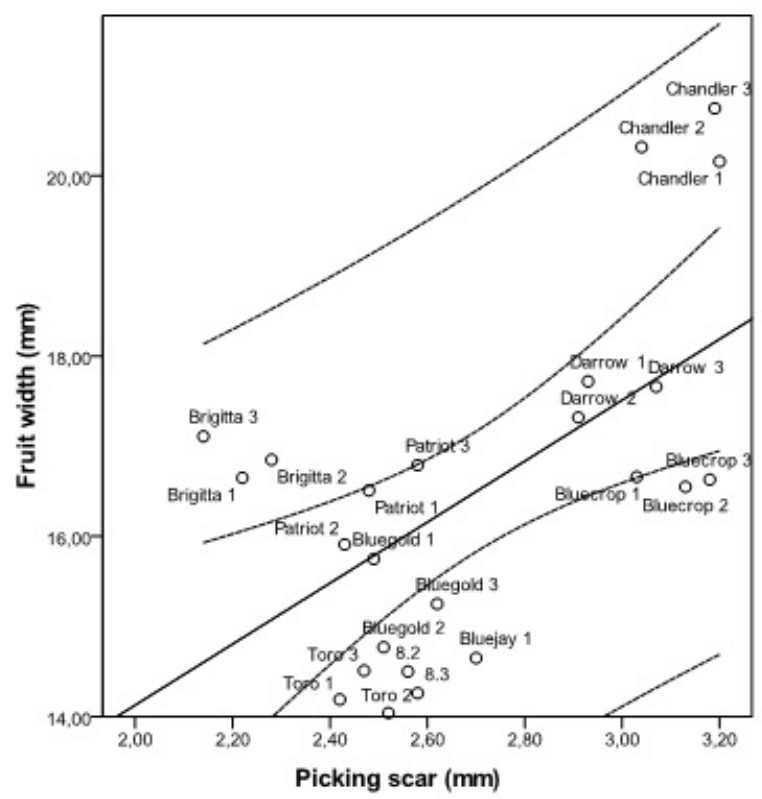

Figure 3. Correlation between fruit width and picking scar size from three replicates for eight commercial cultivars in the second harvest year

\section{Conclusion}

In this study, fruit width varied between 14.22 (Bluejay) - $20.43 \mathrm{~mm}$ (Chandler) in the first year and 14.24 (Toro) - $20.41 \mathrm{~mm}$ (Chandler) in the second year. While Chandler (2.86 - $3.14 \mathrm{~mm})$ had the 
biggest scar size, Patriot and Brigitta (2.14 - 2.21 $\mathrm{mm}$ ) had the smallest scar size by years. In case fruit weight varied $1.81 \mathrm{~g}$ (Bluegold and Bluejay) - $4.22 \mathrm{~g}$ (Chandler) and $1.76 \mathrm{~g}$ (Bluejay) - $3.99 \mathrm{~g}$ (Chandler) respectively to the years.

Consequently, Chandler had the biggest fruits in both years, but this variety has the biggest picking scar diameter. On the other hand, Brigitta has a small dry fruit scar that diminishes to decay after harvest. Also, berry size of this cultivar is greater than many of them. Because of this reasons Brigitta is suitable for far market while Chandler is good for local ones.

\section{References}

Ateş, S., \& Çelik, H. (2013). Dünya ve Türkiye Maviyemiş Üretim Potansiyeli. Hasad Dergisi Bitkisel Üretim, 29(343), 76-80.

Bal, J.J.M., Balkhoven, J.M.T., \& Pepleman, G. (2006). Results of Testing Highbush Blueberry Cultivars In The Netherlands. VIIIth International Symposium on Vaccinium Culture. Acta Horticulturae, 715, 157 162.

Ballington, J.R., Ballinger, W.E., Swalow, W.H., Galletta, G.J., \& Kushman, L.J. (1984). Fruit Quality Characterization of 11 Vaccinium Species. Journal of American Society Horticultural Science, 109,684689.

Ballington, J.R., Isenberg, Y.M., \& Draper, A.D. (1986). Flowering and fruiting characteristics of Vaccinium ashei and Vaccinium ashei-Vaccinium constablaei derivate blueberry progenies. Journal of the American Society for Horticultural Science, 111, 950-955.

Çelik, (2012). Yüksek Boylu Maviyemiş (Highbush Blueberry) Yetiștiriciliği. Gifimey Mesleki Yayınlar Serisi-III, 1-150.

Çelik, H. (2009). Yield and Berry Characteristics of Some Northern Highbush Blueberries Grown at Different Altitudes in Turkey. Acta Horticulturae, 838,63-66.

Dale, A., \& Hancock, J.F. (2005). Highbush blueberry cultivar trial in Ontario, Canada. International Journal of Fruit Science,5(2), 73-76.

Eccher, T., Noe, N., \& Carotti, E. (2006). Field performance of Vaccinium corymbosum and V.ashei cultivars in Northern Italy. VIIIth International Symposium on Vaccinium Culture. Acta Horticulturae, 715, 247 254.

Galletta, G.J., \& Ballington, J.R. (1996). Blueberries, cranberries and lingonberries. In, Janick, J., Moore J.N. (Ed), Fruits Breeding. 2, Vine and Small Fruits Crops New York, NY, Prentice Hall, pp.1-107.
Hancock, J.F., Lyrene, P., Finn, C.E., Vorsa, N., \& Lobos, G.A. (2008). Chapter Blueberries and Cranberries; Temperate Fruit Crop Breeding.

Konarska, A. (2015). Development of Fruit Quality Traits and Comparison of the Fruit Structure of two Vaccinium corymbosum (L.) Cultivars. Scientia Horticulturae, 194, 79-90.

Moggia, C., Beaudry, R.M., Retamales, J.B. \& Lobos, G.A. (2017). Variation in the impact of stem scar and cuticle on water loss in highbush blueberry fruit argue for the use of water permeance as a selection criterion in breeding. Postharvest Biology and Technology, 132, 88-96.

Paprstein, F., Ludvikova, J., \& Sedlak, J. (2009). Evaluation of a germplasm collection of highbush blueberry (Vaccinium corymbosum L.) in the Czech Republic. IX $^{\text {th }}$ International Symposium on Vaccinium. Acta Horticulturae, 810,97-102.

Parra, R., Lifante, Z.D., \& Valdes, B. (2007). Fruit size and picking scar size in some blueberry commercial cultivars and hybrid plants grown in SW Spain. International Journal of Food Science and Technology, 42, 880-886.

Perkins-Veazie, P., Collins, J.K., Clark, J.R., Magee, J., \& Substation, S.F. (1994). Postharvest Quality of Southern Highbush Blueberries. Science, 27, 12541255.

Retamales, J.B., \& Hancock, J.F. (2018). Blueberries. $2^{\text {nd }}$ Ed. CABI Crop Production Science in Horticulture Series, 28, 425p.

Scalzo, J., Dierking, S., Dierking, W., Miller, S., Edwards, C., \& Alspach, P. (2009b). 'Hortblue Poppins', New cultivar for the home garden. IXth International Symposium on Vaccinium. Acta Horticulturae, 810, 157-162.

Scalzo, J., Miller, S., Edwards, C., \& Alspach (2009a). 'Hortblue Onyx' and 'Hortblue Petite', Two New Ornamental Blueberries from New Zealand. IXth International Symposium on Vaccinium. Acta Horticulturae, 810, 153-156.

Siefker, J.H., \& Hancock, J.F. (1986). Yield component interactions in cultivars of the highbush blueberry. Journal of American Society of Horticultural Science, 111(4), 606-608.

Smolarz, K. (2006). Evaluation of Four Blueberry Cultivar Growing in Central Poland. VIIIth International Symposium on Vaccinium Culture. Acta Horticulturae, 715, 81-84.

Starast, M., Paal, T., Vool, E., Karp, K., Albert, T., \& Moor, U. (2009). The productivity of some blueberry cultivars under Estonian conditions. IX ${ }^{\text {th }}$ international 
Symposium on Vaccinium. Acta Horticulturae, 810, 103-108.

Strang, J., Jones, T.R., \& Brown, G.R. (1989). Growing Highbush Blueberries in Kentucky. University of Kentucky College of Agriculture Cooperative Extension Service, HO-60,1-12.
Strik, B.C., \& Finn, C.E. (2008). Blueberry Cultivars for Oregon, Oregon State University, Extension Service, $1-12$. 